\title{
Lysosomal stability, superoxide dismutase and zinc deficiency in regenerating rat liver
}

\author{
BY I. E. DREOSTI AND I. R. RECORD \\ CSIRO Division of Human Nutrition, Adelaide, South Australia 500, Australia
}

(Received 21 November 1977 - Accepted 8 December 1977)

I. Lysosomal stability was slightly increased in regenerating livers from rats receiving a zinc-deficient $(<0.5 \mathrm{mg} / \mathrm{kg}$ ) diet for $10 \mathrm{~d}$ before surgery.

2. The activity of superoxide dismutase (ECI.I5.I.I) was significantly reduced in the same tissues.

3. The results do not support the view that increased lysosomal fragility represents a major biochemical consequence of nutritional $\mathrm{Zn}$ deficiency in animals.

The severe effects of dietary zinc restriction in animals are well documented and in particular a requirement has been noted for $\mathrm{Zn}$ during cell division in actively-growing tissues (Underwood, I97I). Maternal $\mathrm{Zn}$ deficiency during pregnancy in rats is highly teratogenic (Hurley \& Swenerton, 1966) and at present the effect on embryogenesis is generally attributed to the involvement of $\mathrm{Zn}$ in the synthesis of protein and the nucleic acids (Mills, Quarterman, Williams \& Dalgarno, 1967; Somers \& Underwood, 1969; Dreosti, Grey \& Wilkins, 1972).

However, recent studies performed in vitro point to a further role for $\mathrm{Zn}$ as a stabilizer of the lysosomal membrane (Chvapil, Ryan \& Zukoski, 1972), and the suggestion has been made that $\mathrm{Zn}$ deficiency in vivo may lead to diminished lysosomal stability (Chvapil, 1973). The idea derives support from the fact that mammalian superoxide dismutase ( $E C$ I . I 5 I . I) is known to be a copper- $\mathrm{Zn}$ metalloenzyme, which is currently considered to be important for the protection of cellular membranes against damage by free superoxide radicals (Fridovich, 1975). The possibility therefore arises that such damage may be reflected in certain aspects of the $\mathrm{Zn}$ deficiency syndrome. Furthermore, disturbed lysosomal function is strongly implicated as a factor responsible for teratogenesis in animals (Lloyd \& Beck, I969).

Accordingly in the present study an investigation was undertaken into the stability of lysosomes and the activity of superoxide dismutase in regenerating and non-regenerating livers from $\mathrm{Zn}$-deficient and control rats.

\section{METHODS}

Three groups of eight female rats of the Hooded Wistar strain weighing approximately $220 \mathrm{~g}$ were maintained individually in stainless-steel and plastic cages, and given either a $\mathrm{Zn}$-deficient or a $\mathrm{Zn}$-supplemented diet for Io d before partial hepatectomy. Pair-fed rats received daily the same amount of the $\mathrm{Zn}$-supplemented diet as was consumed by their $\mathrm{Zn}$-deficient counterparts during the previous $24 \mathrm{~h}$. Food intake of the $\mathrm{Zn}$-deficient animals fell from around the seventh day of treatment to a level about $60 \%$ of that consumed by the ad lib. Zn-supplemented group.

The Zn-deficient diet (Wilkins, Grey \& Dreosti, 1972) was prepared from EDTAextracted soya-bean flour (Davis, Norris \& Kratzer, 1962) and contained on assay less than $0.5 \mathrm{mg} \mathrm{Zn} / \mathrm{kg}$ diet. The $\mathrm{Zn}$-supplemented rats received the same diet containing an additional $100 \mathrm{mg} \mathrm{Zn}$ as zinc sulphate $/ \mathrm{kg}$. Vitamins were supplied separately in sucrose to all animals three times per week (Hurley \& Swenerton, 1966). 
Partial hepatectomy was performed under diethyl ether anaesthesia as described by Higgins \& Anderson (1931). Liver samples were taken from all animals at the time of surgery and were used for the analysis of 'non-regenerating' tissue. Samples obtained 8 and $16 \mathrm{~h}$ later represented the 'regenerating' tissue and were taken at both times from four animals in each group.

Lysosomes were prepared as the light-mitochondrial fraction in $0.25 \mathrm{M}$-sucrose (Slater, 1974), and lysosomal stability was estimated both from the amount of free $\beta$-glucuronidase (EC 3.2.I.3I) activity in the post-lysosomal supernatant fraction (Sudhakaran \& Kurup, 1974) and from the amount of $\beta$-glucuronidase released from a lysosome suspension after incubation at $\mathrm{pH}_{4.5}$ for $30 \mathrm{~min}$ at $37^{\circ}$ (Owens, Gammon \& Stahl, 1975; Brenner \& Bond, 1977).

Superoxide dismutase was assayed in portions of post-lysosomal supernatant fraction by the photochemical augmentation method developed by Misra \& Fridovich (1977), which is based on the increased photo-oxidation of dianisidine by riboflavin in the presence of superoxide dismutase.

Protein was determined by the method of Lowry, Rosebrough, Farr \& Randall (I95I).

$\mathrm{Zn}$ analyses were performed on plasma samples taken from the animals at the time of slaughter using an atomic absorption spectrophotometer (Varian I 200; Varian Techtron Pty. Ltd, Melbourne, Australia). All results were evaluated using the analysis of variance procedure described by Nie, Hull, Jenkins, Steinbrenner \& Bent (1975).

\section{RESULTS AND DISCUSSION}

Lysosomal stability as reflected by the activity of $\beta$-glucuronidase in the post-lysosomal supernatant fraction (Table 1 ), was similar in all animals at the time of surgery but tended to decrease transiently $8 \mathrm{~h}$ post-operatively in the pair-fed and ad lib. control groups. At this stage no labilization had occurred in the $\mathrm{Zn}$-deficient animals and at $16 \mathrm{~h}$ significantly greater stability $(P<0.01)$ was recorded for the $\mathrm{Zn}$-deficient group than had been observed in these animals at the time of surgery.

In vitro release of $\beta$-glucuronidase (Table I) was significantly higher $(P<0.01)$ from lysosomes prepared from livers of pair-fed control animals at the time of partial hepatectomy than in the corresponding $\mathrm{Zn}$-deficient group or the ad lib.-fed control group. Post-operatively the release of enzyme increased in all groups after $8 \mathrm{~h}$ and had decreased again by $\mathrm{I} 6 \mathrm{~h}$. In the $\mathrm{Zn}$-deficient animals, however, the increase after $8 \mathrm{~h}$ was smaller and the decrease at $\mathrm{I} 6 \mathrm{~h}$ was greater than in the control groups, especially the ad lib.-fed animals.

Both sets of results concerning lysosomal stability suggested greater fragility of the membrane during the early stages ( $8 \mathrm{~h}$ post-operatively) of cell division, although the effect of stress cannot be discounted. The findings tend to corroborate those of Maggi (1966) who demonstrated increased lysosomal permeability during cell division in cultured HeLa cells, and probably represent a routine event in the cell cycle. The enhanced lysosomal stability observed in the $\mathrm{Zn}$-deficient rats may therefore reflect reduced mitotic activity in cells from these animals or, alternatively, since cyclic-AMP is considered to act as a lysosomal stabilizer (Chvapil, 1973) it may arise as a consequence of the increased cyclic-AMP levels observed in $\mathrm{Zn}$-deficient rat livers (Record \& Dreosti, unpublished results). The greater release of $\beta$-glucuronidase from the lysosomes of pair-fed control rats is probably due to the increased lysosomal permeability and catabolic activity associated with starved animals (Pontremoli, Melloni, De Flora, Accorsi, Balestrero, Tsolas, Horecker \& Poole, 1976).

Superoxide dismutase appeared to be unaffected by the dietary regimen in nonregenerating liver tissues but was significantly reduced $(P<0.05) \mathrm{I} 6 \mathrm{~h}$ post-operatively in 
Zinc and lysosomal stability

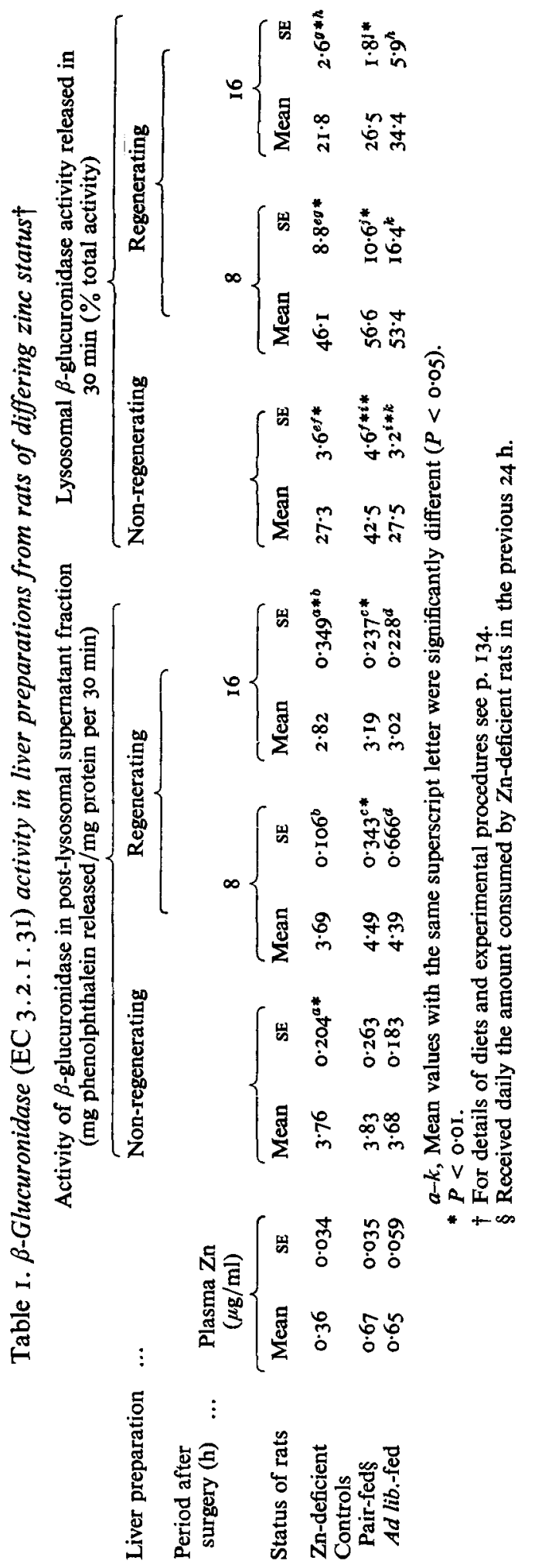


Table 2. Superoxide dismutase (EC I . I 5. I . I) activity in post-lyosomal supernatant fractions from livers of rats of differing zinc status $\dagger$

\begin{tabular}{|c|c|c|c|c|c|c|c|c|}
\hline \multirow{3}{*}{$\begin{array}{l}\text { Liver preparation } \\
\text { Period after } \\
\text { surgery (h) ... }\end{array}$} & & & \multicolumn{6}{|c|}{$\begin{array}{l}\text { Activity of superoxide dismutase } \\
\text { (units\$ enzyme activity/mg protein) }\end{array}$} \\
\hline & & & \multirow{2}{*}{\multicolumn{2}{|c|}{$\begin{array}{c}\text { Non-regenerating } \\
-\end{array}$}} & \multicolumn{4}{|c|}{ Regenerating } \\
\hline & $\begin{array}{r}\text { Plasn } \\
(\mu \mathrm{g}\end{array}$ & & & & 8 & & I6 & \\
\hline Status of rats & Mean & $\mathbf{S E}$ & Mean & $\mathbf{S E}$ & Mean & SE & Mean & $\mathbf{S E}$ \\
\hline $\begin{array}{l}\text { Zn-deficient } \\
\text { Controls }\end{array}$ & 0.36 & 0.034 & $18 \cdot 5$ & $0.87^{2 *}$ & $17 \cdot 0$ & $0.8 \mathrm{I}$ & I $3 \cdot I$ & $0.95^{a * e}$ \\
\hline $\begin{array}{l}\text { Pair-fed\| } \\
\text { Ad lib.-fed }\end{array}$ & $\begin{array}{l}0.67 \\
0.65\end{array}$ & $\begin{array}{l}0.035 \\
0.059\end{array}$ & $\begin{array}{l}19.1 \\
18.6\end{array}$ & $\begin{array}{l}0.96^{b} \\
0.84\end{array}$ & $\begin{array}{l}17.8 \\
17.6\end{array}$ & $\begin{array}{l}0.36 \\
1.09\end{array}$ & $\begin{array}{l}15 \cdot 4 \\
16 \cdot 2\end{array}$ & $\begin{array}{l}1 \cdot 05^{b} \\
1 \cdot 12^{c}\end{array}$ \\
\hline
\end{tabular}

$a-c$, Mean values with the same superscript letter were significantly different $(P<0.05)$.

$* P<0.005$.

$\dagger$ For details of diets and experimental procedures see p. I34.

\# Enzyme activity was completely inhibited in all instances by the addition of potassium cyanide to a final concentration of $0.00 \mathrm{I} \mathrm{M}$.

$\S$ I unit of superoxide dismutase activity is defined as the amount of enzyme required to inhibit the rate of reduction of cytochrome $c$ by $50 \%$ under certain defined conditions (McCord \& Fridovich, 1969).

|| Received daily the amount consumed by $\mathrm{Zn}$-deficient rats in the previous $24 \mathrm{~h}$.

the $\mathrm{Zn}$-deficient group relative to the ad lib. controls (Table 2). All groups exhibited reduced activity at $\mathrm{I} 6 \mathrm{~h}$ but the decrease was greatest in the case of the $\mathrm{Zn}$-deficient animals and reached levels significantly lower $(P<0.005)$ than those in the non-regenerating tissue.

It should be noted that although the levels of superoxide dismutase decreased in the $\mathrm{Zn}$-deficient animals the concentration of the enzyme generally found in cells greatly exceeds the steady-state concentration of superoxide (Williams, Lynch, Lee \& Cartwright, 1975). Whether a decrease in enzyme activity of approximately $30 \%$ is therefore important physiologically is not clear. Certainly in the present study this does not seem to be the situation, on the contrary, the $\mathrm{Zn}$-deficient lysosomes appeared to be more stable.

It should also be noted that the role of $\mathrm{Zn}$ in superoxide dismutase is considered to be a structural one, although some molecular stability as well as the catalytic activity is provided by the attendant cuprous ions (Forman \& Fridovich, 1973). The diminished superoxide dismutase activity in the $\mathrm{Zn}$-deficient livers therefore probably reflects increased breakdown of existing superoxide dismutase as well as a general reduction in protein synthesis.

The present results suggest that in partially-hepatectomized rats, dietary $\mathrm{Zn}$ deficiency does not result in labilization of the liver lysosomes up to $16 \mathrm{~h}$ post-operatively. Since changes have already been noted in the pattern of events leading to the synthesis of liver DNA as little as Io h after surgery in Zn-deficient rats (Duncan \& Dreosti, I976), it must be concluded that in this tissue, lysosomal fragility is not a prime locus of action of $\mathrm{Zn}$ during cell division.

\section{REFERENCES}

Brenner, E. B. \& Bond, J. (1977). Proc. Soc. exp. Biol. Med. 140, 642.

Chvapil, M. (1973). Life Sci. 13, 104I.

Chvapil, M., Ryan, J. M. \& Zukoski, C. F. (1972). Proc. Soc. exp. Biol. Med. 140, 642.

Davis, P. N., Norris, L. C. \& Kratzer, F. H. (I962). J. Nutr. 78, 445.

Dreosti, I. E., Grey, P. C. \& Wilkins, P. J. (1972). S. Afr. med. J. 46, 1585. 
Duncan, J. R. \& Dreosti, I. C. (1976). J. comp. Path. 86, 81.

Forman, H. J. \& Fridovich, I. (1973). J. biol. Chem. 41, 2645.

Fridovich, I. (1975). A. Rev. Biochem. 44, 147.

Higgins, G. M. \& Anderson, R. M. (193I). Archs Path. 12, I86.

Hurley, L. S. \& Swenerton, H. (1966). Proc. Soc. exp. Biol. Med. 123, 692.

Lloyd, J. B. \& Beck, F. (1969). In Lysosomes in Biology and Pathology, vol. 1, p. 433 [J. T. Dingle and H. B. Fell, editors]. Amsterdam: North Holland.

Lowry, O. H., Rosebrough, N. J., Farr, A. L. \& Randall, R. J. (I95I). J. biol. Chem. 193, 265.

McCord, J. M. \& Fridovich, I. (1969). J. biol. Chem. 244, 6049.

Maggi, V. (1966). Jl R. microsc. Soc. 85, 291.

Mills, C. F., Quarterman, J., Williams, R. B. \& Dalgarno. A. C. (1967). Biochem. J. 102, 712.

Misra, H. P. \& Fridovich, I. (1977). Archs Biochem. Biophys. 18r, 308.

Nie, N. H., Hull, C. H., Jenkins, J. G., Steinbrenner, K. \& Bent, D. H. (1975). Statistical Package for Social Sciences, and ed. New York: McGraw-Hill,

Owens J. W., Gammon, K. L. \& Stahl, P. D. (1975). Archs Biochem. Biophys. x66, 258.

Pontremoli, S., Melloni, E., De Flora, A., Accorsi, A., Balestrero, F., Tsolas, O., Horecker, B. L. \& Poole, B. (1976). Biochimie 85, 149.

Slater, T. F. (I974). In Companion to Biochemistry, vol. I, p. 5 I 2 [A. T. Bull, J. R. Lagnado, J. O. Thomas and K. F. Tipton, editors]. London: Longman.

Somers, M. \& Underwood, E. J. (1969). Aust. J. biol. Sci. 22, 1277.

Sudhakaran, P. R. \& Kurup, P. A. (1974). J. Nutr. 104, 1466.

Underwood, E. J. (1971). Trace Elements in Human and Animal Nutrition, 3rd ed. New York: Academic Press.

Wilkins, P. J., Grey, P. C. \& Dreosti, I. E. (1972). Br. J. Nutr. 27, 113.

Williams, D. M., Lynch, R. E., Lee, G. R. \& Cartwright, G. E. (1975). Proc. Soc. exp. Biol. Med. 149, 534. 